\title{
Keeping California Cool: Recent cool community developments
}

\author{
Haley Gilbert $^{\mathrm{a},{ }^{*}, \text { Benjamin Mandel }^{\mathrm{a}} \text {, Ronnen Levinson }}{ }^{\mathrm{a}}$
}

\section{ABSTRACT}

In 2006, California introduced the Global Warming Solutions Act (Assembly Bill 32), which requires the state to reduce greenhouse gas emissions to 1990 levels by 2020 . "Cool community" strategies, including cool roofs, cool pavements, cool walls and urban vegetation, have been identified as voluntary measures with potential to reduce statewide emissions. In addition, cool community strategies provide co-benefits for residents of California, such as reduced utility bills, improved air quality and enhanced urban livability. To achieve these savings, Lawrence Berkeley National Laboratory (LBNL) has worked with state and local officials, non-profit organizations, school districts, utilities, and manufacturers for four years to advance the science and implementation of cool community strategies. This paper summarizes the accomplishments of this program, as well as recent developments in cool community policy in California and other national and international efforts. We also outline lessons learned from these efforts to characterize successful programs and policies to be replicated in the future.

Keywords: cool communities; cool roofs; cool pavements; cool schools; local government; California; California Assembly Bill 32 (AB32)

\section{Introduction}

In 2006, California introduced the Global Warming Solutions Act (Assembly Bill 32 2006), which requires California to reduce greenhouse gas emissions to 1990 levels by 2020 [1]. It is the most ambitious climate policy that has been passed at the state or federal level in the United States to date. As California policymakers seek innovative measures to achieve this reduction, they are evaluating both mandatory and voluntary solutions. "Cool community" strategies, including cool roofs, cool pavements, cool walls, and urban vegetation, have been identified as voluntary measures with potential to reduce statewide emissions. These cool community strategies also mitigate the urban heat island effect, or elevation in city temperatures relative to surrounding areas. Co-benefits of heat island mitigation include reduced utility bills, improved air quality and health, fortified climate resilience and enhanced urban livability for residents of California. To help achieve these savings, Lawrence Berkeley National Laboratory (LBNL) has worked with state and local officials, non-profit organizations, school districts, utilities, and manufacturers for four years to advance the science and implementation of cool community strategies. Several entities have successfully adopted these measures—school districts are rethinking their schoolyards and rooftops, cities are achieving climate action and adaptation with cool community measures, and the state of California is showing climate leadership by developing guidance to help cities adapt to changing conditions. All of these policy developments are shaping a cooler future for California.

\footnotetext{
* Corresponding Author: HEGilbert@LBL.gov, +1-510-486-7325.

${ }^{a}$ Heat Island Group, Lawrence Berkeley National Laboratory, One Cyclotron Rd., Building 90, Berkeley, CA, USA 94720
}

\section{$1 / 12$}


This paper presents several recent programs and policies in California that address heat island mitigation measures. We also briefly describe efforts underway in other jurisdictions in North America and internationally to deploy cool community measures. Based on these examples in California and elsewhere, we conclude by offering observations on the characteristics that contribute to the success of these programs and that should therefore guide future cool community measures.

\section{Recent developments: successful cool community programs and policies in California}

\subsection{School Districts}

There are close to 10,000 schools across California with annual energy expenses totaling US\$700 million [2,3]. Schools would therefore stand to benefit from adoption of cool community measures to reduce their energy costs. In addition, schools are among the largest building and pavement owners in California cities, so they are heavily invested in measures that can be optimized to improve environmental performance.

School districts in California operate with a high degree of local autonomy; they receive guidance from the state but do not fall under the local jurisdictions of the cities in which they reside. The size, complexity and operations of school districts has made it difficult for many districts to employ new technologies. However, two school districts in California, Los Angeles Unified School District (LAUSD) and Sacramento County Unified School District (SCUSD), reached out to LBNL for help in understanding the science and potential benefits of cool community measures, and are on track to adopt innovative and cool programs as a result.

Los Angeles Unified School District's cool schoolyards pilot. In 2012, LBNL began convening a group of school stakeholders to help identify the barriers and opportunities for the adoption of cool pavements at schools. Many California schoolyards are large areas of blacktop (asphalt concrete) with lines for various game and activities painted on them (Figure 1). Many cool pavement options come in a variety of colors, so in addition to making schoolyards cooler, cool colored pavement strategies also can be used to beautify schools.

\section{[FIG 01 - Gardena Elementary School.jpg]}

Figure 1. Gardena Elementary School in Gardena, California. The schoolyard is almost entirely blacktop with lines painted on the surface to outline games or activities. Source: Google Earth

The stakeholder group includes more than 50 participants representing pavement manufacturers, the California Governor's Office of Planning and Research, the California Department of Education, local school districts, landscape architecture firms, and LBNL. From these early discussions and meetings, LBNL developed technical resources tailored for school districts, and pavement manufacturers began to develop cool products for this stakeholder group with specific performance and cost targets in mind.

LAUSD was the first school district to ask LBNL to help them implement a pilot program. LAUSD is the second largest school district in the United States, with more than 1000 school facilities [4]. Los Angeles is the largest city in California, located along the coast in the southern part of the state. The city experiences mild winters with dry, warm summers. LBNL 
worked closely with LAUSD to develop a cool schoolyard pilot project that would keep schoolyard conditions more comfortable, especially during the warmer months of the year. LAUSD intended for this project to encourage innovation of cool pavement products, develop a district design standard, and train staff on the application/construction of these new products.

LAUSD staff members Chad Fenwick, Advisor to Physical Education, and Roshini Das, Sustainability Specialist in the Facilities Services Division, spearheaded the pilot project. The district's goal was to find products that are available in a range of cool colors to brighten the schoolyard and could be applied by their in-house facilities staff. First, the team met with product manufacturers to learn about currently available products and to see which products met the district's goals. Next, the team reviewed the most promising products with the district's New Products Committee, which is comprised of maintenance, planning, operations, procurement, design, safety and sustainability staff. This was an important step to get buy-in and support from various departments within the district. The committee selected several candidate products to submit for approval to the district's Office of Environmental Health \& Safety. To date, two products have been approved by the Office of Environmental Health \& Safety as safe to use in the district, while a third was not approved. Since district regulations only permit design standards with a minimum of three product options, the goal is to construct three pilot projects. During the summer of 2013, construction was completed on the first pilot with Quest Construction Product's StreetBond coating at Gardena Elementary School in Gardena, CA. The epoxy-acrylic coating is durable and colorful, and can be applied over existing blacktop surfaces at the time of resurfacing. Most schoolyards in California undergo routine resurfacing every 5-7 years on the blacktop schoolyards. Often a seal coat is applied to the surface to protect the asphalt pavement system. Conventional seal coats are asphalt-based and are therefore typically black in color, ranging in initial solar reflectance from 0.05 to 0.15 . The cool schoolyard coatings protect the pavement system and provide a more reflective surface, with solar reflectance values between 0.31 and 0.44 , which allows them to absorb less sunlight than conventional seal coats and should allow them to last longer. Figure 2 illustrates LAUSD's first pilot cool schoolyard design (subfigure a), the pre-existing blacktop (subfigure b), the application of the cool coating by the district staff (subfigure c), and the completed project (subfigure d). Currently, the district is planning the second pilot project and LBNL is working with the district to identify the final product for the third pilot.

(a)

[FIG 02a - Proposed Gardena Design.jpg]

(c)

[FIG 02c - Cool Coating Application.jpg] (b)

[FIG 02b - Gardena Blacktop.png]

(d)

[FIG 02d - Gardena Completed.jpg]
112

113

114

115

116

117

118
Figure 2. Image (a) is the proposed design of the Gardena Elementary School cool schoolyard and image (b) shows the pre-existing blacktop area that was coated in the summer of 2013. Image (c) was taken during the application of the cool coating and image (d) shows the completed project. Sources: Los Angeles Unified School District and Streetbond 2013.

Progress for cool pavements at other California schools. In addition to the pilot project in LAUSD, other school districts in California are now changing their pavement practices. One of the other cool pavement manufacturing partners, Western Colloid, applied its cool seal coat at 
four schools in Palmdale Unified School District in southern California (Figure 3a). Cool schoolyard policies were adopted as part of design guidance at West Contra Costa Unified School District in the northern part of the state (Figure $3 b$ ).

(a)

[FIG 03a - Palmdale Seal Coat.jpg] (b)

[FIG 03b - MLK Cool Schoolyard.jpg]
122

123

Figure 3. Image (a) is cool seal coat used in the Palmdale school district; image (b) shows a cool schoolyard at Martin Luther King Elementary School in Richmond, California. Source: Western Colloid 2013 (left) and Bill Savidge, former engineering officer for West Contra Costa Unified School District (right).

Sacramento City Unified School District's cool roof analysis. Sacramento is the capital city of California, located in the northern portion of the state's central valley. Sacramento has a Mediterranean climate, with mild, wet winters and dry, hot summers. Many of SCUSD's facilities feature dark asphaltic roofing products that are now in need of repair. The initial response by the district was to undertake costly roof replacements. However, one of the staff members, Ron Rudi, from the Facilities Division at SCUSD contacted LBNL to learn more about cool roof coating options. Their preliminary research suggested that a coating would extend the life of the existing roof, but they also wanted to quantify the potential energy cost savings from converting their dark roofs to white roofs. The LBNL team collaborated with the SCUSD Facilities Division to conduct a high-level analysis of the cost and emissions savings for 85 schools with combined conditioned roof area of more than $450,000 \mathrm{~m}^{2}$. The analysis used postalcode level energy savings estimates and emissions factors from Levinson and Akbari [5] to assess the potential benefits of applying white roof coatings, adjusting for (a) efficiency of HVAC equipment used in SCUSD facilities, and (b) current energy prices.

The analysis revealed that by installing white roof coatings on their schools, SCUSD could save more than US\$670,000 annually, net of heating penalties attributable to lower solar absorption during the heating season. Table 1 highlights the estimated potential for total annual cost savings for SCUSD by postal code and conditioned roof area, as well as the potential for reductions in emissions from conserved energy in the district. The Facilities Division presented these findings to district management and received funding to move forward with white roof coatings on the school facilities. To date, they have applied white coatings to more than 70,000 $\mathrm{m}^{2}$ of roof on 30 schools.

147 Table 1. LBNL collaborated with SCUSD to estimate the potential annual energy-cost and emission 148 savings from applying a white coating to the school buildings

\begin{tabular}{|c|c|c|c|c|c|c|c|}
\hline $\begin{array}{c}\text { Postal } \\
\text { code }\end{array}$ & $\begin{array}{c}\text { \# of } \\
\text { schools }\end{array}$ & $\begin{array}{c}\text { Total } \\
\text { conditioned } \\
\text { roof area } \\
\left(1000 \mathrm{~m}^{2}\right)\end{array}$ & $\begin{array}{c}\text { Total } \\
\text { annual } \\
\text { energy-cost } \\
\text { saving } \\
(\mathrm{US} \$ \mathrm{~K})\end{array}$ & $\begin{array}{c}\text { Total annual } \\
\mathrm{CO}_{2} \\
\text { reduction } \\
(\mathrm{t})\end{array}$ & $\begin{array}{c}\text { Total annual } \\
\mathrm{NO}_{\mathrm{x}} \\
\text { reduction } \\
(\mathrm{kg})\end{array}$ & $\begin{array}{c}\text { Total annual } \\
\mathrm{SO}_{2} \\
\text { reduction } \\
(\mathrm{kg})\end{array}$ & $\begin{array}{c}\text { Total } \\
\text { annual Hg } \\
\text { reduction } \\
(\mathrm{mg})\end{array}$ \\
\hline 95811 & 1 & 3 & 4.9 & 13 & 11 & 8 & 34 \\
\hline 95816 & 3 & 16 & 23.4 & 62 & 53 & 39 & 162 \\
\hline 95817 & 2 & 8 & 11.5 & 30 & 26 & 19 & 79 \\
\hline 95818 & 8 & 52 & 76.6 & 202 & 174 & 129 & 529 \\
\hline
\end{tabular}




\begin{tabular}{|c|c|c|c|c|c|c|c|}
\hline 95819 & 5 & 20 & 29.8 & 79 & 68 & 50 & 206 \\
\hline 95820 & 10 & 62 & 92.2 & 243 & 210 & 155 & 637 \\
\hline 95822 & 17 & 72 & 106.0 & 280 & 242 & 178 & 732 \\
\hline 95823 & 6 & 46 & 68.1 & 180 & 155 & 114 & 470 \\
\hline 95824 & 10 & 52 & 77.5 & 204 & 177 & 130 & 535 \\
\hline 95826 & 6 & 26 & 37.9 & 100 & 86 & 64 & 262 \\
\hline 95827 & 5 & 37 & 54.5 & 144 & 124 & 92 & 377 \\
\hline 95828 & 1 & 3 & 4.9 & 13 & 11 & 8 & 34 \\
\hline 95831 & 7 & 41 & 61.1 & 161 & 139 & 103 & 422 \\
\hline 95832 & 4 & 15 & 22.7 & 60 & 52 & 38 & 157 \\
\hline
\end{tabular}

In recent years, several cities in California have adopted cool community policies,

Chula Vista's climate adaptation plan. Chula Vista is located along California's southern coast. It is part of the greater San Diego metropolitan region and has a climate very similar to that of Los Angeles. In 2000, the city adopted a Carbon Dioxide Reduction Plan, which received national recognition for the city by achieving large reductions in greenhouse gas (GHG) emissions. In 2009, the City Council directed city staff to reconvene their Climate Change Working Group to develop a plan to reduce the city's vulnerability to local climate change impacts. The city expects an increase in local temperatures of $2.5^{\circ} \mathrm{C}$ by 2050 [6] and has therefore prioritized measures to adapt to and mitigate urban heat. Its climate adaptation plan was one of the first in the nation and included measures for cool roofs, cool pavements and shade trees [7].

The implementation plan for cool pavements called for a two-year exploratory project to learn more about the local prospects for cool pavements. The ultimate goal of the cool pavements implementation plan is to develop a new municipal policy that incorporates cool paving materials in new street and parking lot projects. The Public Works Department, which will develop a pilot project to test different cool pavement products, commissioned a study to evaluate their feasibility in the city. The Chula Vista Cool Pavements Study identifies several technologies that offer considerable urban heat island reduction potential, such as light-colored cement concrete products and cool pavement coatings, as well as possible funding sources for a new pavements program. The study sets forth criteria for suitable cool pavement pilot sites, as well as standards for performance monitoring of pilots to assess solar reflectance, thermal emittance, durability, stormwater effects, and noise over time [8]. The intended results of the pilot program will inform Chula Vista's guidelines for new paving as well as for pavement maintenance within five years from the study's date of publication. To date, the pilot program 
has not yet been constructed. Although the implementation plan is not complete, the citywide cool pavement feasibility is the first in the state and is a resource to other cities.

The city's implementation plan for cool roofs included a cost-benefit analysis in

partnership with the local electric utility, San Diego Gas \& Electric, to evaluate what type of policy should be adopted and where. The results of this analysis informed a 2012 revision to the city building code to adopt more stringent cool roof requirements for new low-rise residences. All new building construction and retrofits/renovations in Chula Vista already must comply with the state's cool roof requirements in the building energy efficiency code, but this policy exceeds those minimum radiative property (i.e., solar reflectance and thermal emittance) values. Again, the city's policy to exceed the state's minimum cool roof values was the first-of-its-kind in the state, and as such required (and received) special approval from the California Energy Commission.

Los Angeles' cool roof ordinance and cool pavement development. Los Angeles can greatly benefit from cool community measures because of its climate and size. A 2011 report estimated that Los Angeles residents would save $\$ 30$ million each year if cools roofs were mandated for new and existing buildings [9]. However, those estimates were calculated for today's climate. A second report by Hall et al. [10] revealed that the Los Angeles region could experience temperature increases of up to $2.5^{\circ} \mathrm{C}$ by 2050 . A warmer climate would increase the potential energy savings resulting from cool roofs by increasing number of hours per year in which air conditioning is needed. However, in addition to the energy saving potential of cool community measures, Los Angeles is keen to implement strategies to improve its resiliency to future climate change impacts.

The Los Angeles cool roof report [9] was conducted in consultation with LBNL. The report received attention from the media and the city's administration. The report also attracted interest from a local non-profit, Climate Resolve, which focuses on creating and communicating ideas to mitigate and adapt to climate change in Los Angeles. Because cool surfaces provide both mitigation and adaptation to climate change, they became a cornerstone topic for Climate Resolve, which contacted LBNL for technical assistance that would facilitate the realization of the citywide benefits projected in the city's cool roof report. These recommendations included utility incentives, consumer education and resources, and ultimately cool roof requirements for the city's building code. Climate Resolve hosted a cool roof conference for the region in 2013 that brought together many of the local stakeholders, including then-mayor Antonio Villaraigosa. The organization collaborated with the local municipal utility provider, the Los Angeles Department of Water and Power (LADWP). LADWP already understood the energy savings potential of cool roofs and offered a small cool roof rebate program for consumers. With support from the city's administration, Climate Resolve and LADWP worked with the Los Angeles Department of Building and Safety to develop an update to its Municipal Building Code that required all new and refurbished homes to have a cool roof. The measure was unanimously passed by the Los Angeles City Council in December 2013, and its mandate of cool roofs for all residences exceeds the state's current cool roof requirements in the building energy efficiency code. To roll out the new requirement, LADWP has expanded its consumer incentives, in the form of rebates to its ratepayers that mitigate the cost premium paid for cooler roof products. This is the first comprehensive residential cool roof legislation in the country.

Los Angeles has embraced the idea of cool surfaces and is now exploring the development and adoption of cool pavement measures. The city's Department of Public Works

\section{$6 / 12$}


Bureau of Street Services (BOSS) is spurring development of a new cool pavement product that is similar to the slurry seal currently used in the city for pavement maintenance, but is more reflective. The traditional asphalt slurry seal is very dark, but the city has found a manufacturing partner to explore the development of a lighter-colored product. The manufacturer is now working with LBNL, Climate Resolve and BOSS to develop the product to meet the city's performance, application, and solar reflectance requirements. If product development is successful, the city will conduct a large pilot project in summer 2015. If the pilot is successful, this product could eventually replace the traditional dark slurry seal and become the maintenance practice for the 10,000 miles of city streets in Los Angeles. In addition, other city departments will be developing smaller pilots of various cool pavement materials in 2015.

\subsection{State Government}

The local efforts described above complement new California state policies that incorporate cool community strategies into planning measures.

Cool pavement legislation. In 2012 the state passed the first cool pavement legislation that mandates the California Department of Transportation (Caltrans) to draft cool pavement specifications for use by local jurisdictions and the California Environmental Protection Agency (CAL/EPA) to develop an index for heat islands throughout the state [11]. The heat island index is currently under development and should be completed by summer 2015. It is intended to allow California cities to set quantifiable goals for heat reduction, including means to measure heat and GHG reduction benefits of various cool or sustainable materials strategies. Caltrans will use the index to develop specifications for pavement products that mitigate heat islands.

Extreme heat guidance and recommendations. The state also released guidance and recommendations to help California prepare for extreme heat events. This effort began with the Governor's Conference on Extreme Climate Risks and California's Future in 2012. This conference drew upon case studies featuring successful deployment of cool community measures to help CA cities alleviate, and adapt to, extreme heat events. As a follow up from the conference, Governor Brown encouraged the development of the Extreme Heat Adaptation Guidance Report \& Recommendations. The final guidance was released in 2013, and includes several cool community strategy recommendations developed in consultation with LBNL [12]. The recommendations were drafted by a multi-agency working group and are aimed at the state government level, but are also applicable to regional and local government entities. They include expanded use of cool and porous pavements, and consideration of adding to California's 'Title 24' Building Energy Efficiency Standards [13] provisions that could contribute to community cooling, such as the use of cool pavements.

\section{Cool community programs beyond California}

While California has been an international pioneer in the research, development, and deployment of cool community measures, efforts in other jurisdictions throughout North America and internationally are establishing these strategies as a global trend. Similar to California's statewide initiative, several North American cities have begun to develop extreme 
heat mitigation and adaptation plans. Upon learning that it is one of the most rapidly warming cities in the United States [14] Louisville, Kentucky (USA) has received funding to conduct a comprehensive urban heat island study and develop a heat mitigation plan, which will include cool community provisions,. After studying the interactions between increasingly frequent heat waves and health equity, Toronto, Ontario (Canada) developed extreme heat adaptation guidelines that acknowledge the role roofs and pavements can play in improving health outcomes [15].

Other U.S. cities are embracing cool community strategies in pursuit of social cobenefits. In New York City and Baltimore, Maryland, for instance, city-backed programs support the installation of cool roofs on urban buildings as a way to offer workforce preparedness. Volunteers of the NYC ${ }^{\circ}$ CoolRoofs program, a collaborative initiative of the New York City Department of Buildings and New York City Service, have coated more than $600,000 \mathrm{~m}^{2}$ of New York City rooftops white since its inception in 2009. Many of the program's volunteers are involved in green jobs training programs that allow them to gain hands-on work experience through roof coating [16]. In Baltimore, cool roofs have been identified as a promising solution to mitigate severe summer heat [17]. To accelerate adoption of cool roofs in the city, Baltimore's service corps nonprofit, Civic Works, has added cool roofs to the portfolio of its EnergyReady program. EnergyReady provides home energy assessments and improvement services that create green jobs, and now includes cool roof applications as one of its standard energy improvement measures [18].

Cities outside North America are also taking action to moderate urban heat. This necessity has been well understood in Paris, France since the deadly heat wave of August 2003. From 2007 through 2012, a research collaborative sought to understand and document the extent and variability of the urban heat island in Paris. An urban planning effort ultimately released the findings with preliminary recommendations for measures to adapt to a warming climate in Paris, including the use of cool community measures to create "urban cool islands" [19]. In Melbourne, Australia, where the downtown business area was found to get up to $5^{\circ} \mathrm{C}$ warmer than surrounding suburbs on hot summer days, the city has invested in green infrastructure throughout the city. These interventions, including a property-secured financing mechanism for building energy efficiency upgrades (including cool roofs) and a campaign to increase shade tree cover, earned the city a C40 and Siemens City Climate Leadership Award [20]. Elsewhere in Australia, Sydney has undertaken a study of how shade trees and pavement color can influence urban temperatures, with a focus on the health impacts for humans and ecosystems. The city has implemented a real-time monitoring system that enables the public to track heat island conditions throughout the city instantaneously, and has also completed a "pale pavement" demonstration project [21].

\section{Characteristics of successful programs/policies}

We have observed several common factors across the efforts described above. To be successful, they relied on strong leadership, enjoyed broad stakeholder support, featured complementarities with other policy objectives, and made use of access to local research and technical assistance.

All of the Californian examples of programs and policies benefited from strong leadership in high political offices and/or with staff empowered within organizations. Finding strong leadership seems to be a critical component of cool community programs since often there 
is a need for continued commitment and education of key stakeholders. At the state level, the cool pavement legislation was backed by a well-respected state representative, Assemblymember Nancy Skinner, who cultivated broad political support of the legislation. The state extreme heat guidance came out of a directive from the state governor, while the Los Angeles cool roof ordinance was supported by the mayor and city council; these examples also benefitted from strong public leadership on this issue. The local school district efforts found local staff leadership in the Facilities Divisions that was able to lead the efforts and was committed to bringing stakeholder support to the projects.

This broad and diverse stakeholder support is another common characteristic across cool community efforts in California. To be successful, these strategies require buy-in from various actors, such as maintenance staff, building code officials, and the local city council. While there are mandates or programs that come into effect without broad support and participation of stakeholders, cool community programs seem to be more successful when there is collective support. For example, in Los Angeles the cool roof ordinance enjoyed broad stakeholder support from various city departments, local academics, non-profits, and cool roof manufacturers. This diverse participation likely contributed to the unanimous support of the new cool roof ordinance; stakeholder collaboration on how best to adopt and implement the ordinance to the benefit of all parties minimized potential for negative political push-back. This productive collaboration was embodied by LADWP's extension of its existing cool roof rebate to ease the financial burden of the policy. LAUSD also found that it would need full support of the maintenance, planning, and procurement departments, including the worker unions, for a pilot program to be viable.

Both Californian and international jurisdictions have adopted cool community measures because they promote other policy objectives-climate adaptation and heat resilience. This was particularly true for Chula Vista and Paris, where cool urban surfaces were recommended as measures to mitigate the human health impacts of rising urban temperatures. The multiple benefits of cool strategies lets them win support from a larger alliance of stakeholders. They can also help to fulfill multiple policy objectives, making them even more attractive.

Finally, another common characteristic across all of these examples was the close interaction with and access to local research and technical assistance. Staff from LBNL and other research institutions provided the scientific basis of the Californian policies, and guided the development of the programs toward intended objectives. Many of these organizations often do not have the capacity or in-house technical knowledge to easily implement cool community strategies. Frequently, there are uncertainties relating to the potential benefits, unintended consequences, implementation requirements, and cool surface material development. Access to technical staff gives these organizations confidence in their decisions and the knowledge to ably educate others on the important considerations of cool community strategies. The case studies in Paris and in two Australian cities further demonstrate the importance of partnership with local researchers to better understand the features of local heat islands and the opportunities for heat island mitigation.

\section{Conclusions}

Cool community strategies offer great promise as a way to reduce energy use and improve the livability of cities by mitigating urban heat islands. In light of this potential, more cities, school districts, and organizations should develop policies, programs and projects to support sustained and growing adoption. Fortunately, successful programs and policies have

\section{$9 / 12$}


emerged in recent years in California and beyond that can serve as a model for wider implementation. We have observed that the recipe for success of cool community efforts includes empowered leadership, broad stakeholder backing, support of other policy objectives, and guidance from researchers to ensure sound implementation of promising science.

\section{Acknowledgements}

This work was supported by the California Energy Commission through its Public Interest Energy Research Program (PIER) and the California Air Resources Board. It was also supported by the Assistant Secretary for Energy Efficiency and Renewable Energy, Office of Building Technology, State, and Community Programs, of the U.S. Department of Energy under Contract No. DE-AC02-05CH11231. We wish to thank Roshini Das and Chad Fenwick (Los Angeles Unified School District); Ron Rudi, Jeff Bozeman, Farah Wissinger (Sacramento City Unified School District); Craig Tranby (Los Angeles Department of Water and Power); David Fink (Climate Resolve); Kathy Dervin; Michael Bedard (California State Senate); Brendan Reed (City of Chula Vista); Ken Alex and Sandy Goldberg (Governor's Office of Planning and Research); Doug Davenport (Prospect Silicon Valley); Bill Savidge (California Department of General Services); Steve Jackson (Western Colloid); Kevin Donnelly (Western Emulsions, Inc.); Glen McCrady and Jacob Dobson (Quest Construction Products); and Kurt Shickman (Global Cool Cities Alliance). 
[1] California Global Warming Solutions Act of 2006 (AB 32). 2006. Cal. Health \& Safety Code. $\$ \S 38500$ - 38,599. http://www.leginfo.ca.gov/pub/05-06/bill/asm/ab_00010050/ab_32_bill_20060927_chaptered.pdf.

[2] California Department of Education. 2011. School Facilities Fingertips Facts. Accessed January 2014. http://www.cde.ca.gov/ls/fa/sf/facts.asp.

[3] CEC (California Energy Commission). Consumer Energy Center. Energy tips for Schools. California Energy Commission Consumer Energy Center. Accessed January 2014. http://www.consumerenergycenter.org/tips/schools.html.

[4] Das, R. (Sustainability Specialist at Los Angeles Unified School District) in discussion with the author, September 2013.

[5] Levinson, R., H. Akbari. 2010. "Potential benefits of cool roofs on commercial buildings: conserving energy, saving money, and reducing emission of greenhouse gases and air pollutants." Energy Efficiency. 3: 53-109.

[6] Messner, S., S.C. Miranda, E. Young, N. Hedge. 2011. "Climate-change related impacts in the San Diego region by 2050.” Climatic Change. 109 (Suppl 1):S505-S531.

[7] City of Chula Vista. 2011. Climate Adaptation Strategies - Implementation Plans. http://www.chulavistaca.gov/clean/conservation/Climate/documents/ClimateAdaptationStrat egiesPlans_FINAL_000.pdf.

[8] Nichols (Nichols Consulting Engineers, Chtd.) and CTL Group. 2012. Cool Pavements Study (Final). Prepared for: City of Chula Vista. https://www.chulavistaca.gov/clean/PDF/CVCoolPavementsStudy_FINAL.pdf.

[9] Horowitz, C. 2011. "Bright roofs, big city: Keeping L.A. cool through an aggressive coolroof program." Anthony Pritzker Environmental Law and Policy Briefs 2: 14 pp. http://www.coolrooftoolkit.org/wp-content/uploads/2012/05/UCLABright_Roofs_Big_City.pdf.

[10] Hall, A., F. Sun, D. Walton, S. Capps, X. Qu, H.-Y. Huang, et al. 2012. "Mid-century warming in the Los Angeles Region - Part I of the "Climate Change in the Los Angeles Region' project.” http://escholarship.org/uc/item/6v88k76b.

[11] California Department of Transportation: paving materials (AB 296). 2012. Cal. Health \& Safety Code. $\$ 18941.9$. http://leginfo.legislature.ca.gov/faces/billNavClient.xhtml?bill_id=201120120AB296.

[12] CAL/EPA (California Environmental Protection Agency) and CDPH (California Department of Public Health). 2013. Preparing California for Extreme Heat Guidance and 


\section{Recommendations.}

http://www.climatechange.ca.gov/climate_action_team/reports/Preparing_California_for_Ext reme_Heat.pdf.

[13] CEC (California Energy Commission). 2012. 2013 Building Energy Efficiency Standards, Title 24, Part 6. California Energy Commission, Document CEC-400-2012-004-CMF. http://www.energy.ca.gov/title24.

[14] Stone, B., J. Vargo, D. Habeeb. 2012. "Managing climate change in cities: Will climate action plans work?" Landscape and Urban Planning. 107: 263-271.

[15] Toronto Public Health. 2011. Climate Change Adaptation and Health Equity Background Report. Technical report. http://www1.toronto.ca/City\%200f\%20Toronto/Toronto\%20Public\%20Health/Healthy\%20P ublic\%20Policy/PDF\%20Reports\%20Repository/climate_change_health_equity.pdf.

[16] City of New York. 2015. NYC ${ }^{\circ}$ CoolRoofs. Accessed online 22 May 2015. http://www.nyc.gov/html/coolroofs/html/home/home.shtml.

[17] Jacobson, J. 2013. “Cool Roofs for a Cool Baltimore: An Environmental Weapon Against Climate Change, Air-Conditioning Costs, and Sweltering Summer Heat." The Abell Report. 26(6): 1-12.

[18] EnergyReady. 2015. Civic Works EnergyReady. Accessed online 22 May 2015. http://www.energyreadynow.com/what-we-do/cool-roofs.

[19] Parisian Urban Planning Workshop (APUR). 2012. Urban heat islands in Paris - Book 1. http://www.apur.org/sites/default/files/documents/ilot_chaleur_urbains_paris_cahier1.pdf.

[20] City Climate Leadership Awards, 2013-2014. How Melbourne Plans to Mitigate the Urban Heat Island Effect. Accessed online 22 May 2015.

http://cityclimateleadershipawards.com/mayors-voices-melbourne-lord-mayor-robert-doyle/.

[21] City of Sydney. 2015. Urban heat island effect. Accessed online 28 May 2015. http://www.cityofsydney.nsw.gov.au/vision/towards-2030/sustainability/carbonreduction/urban-heat-island. 

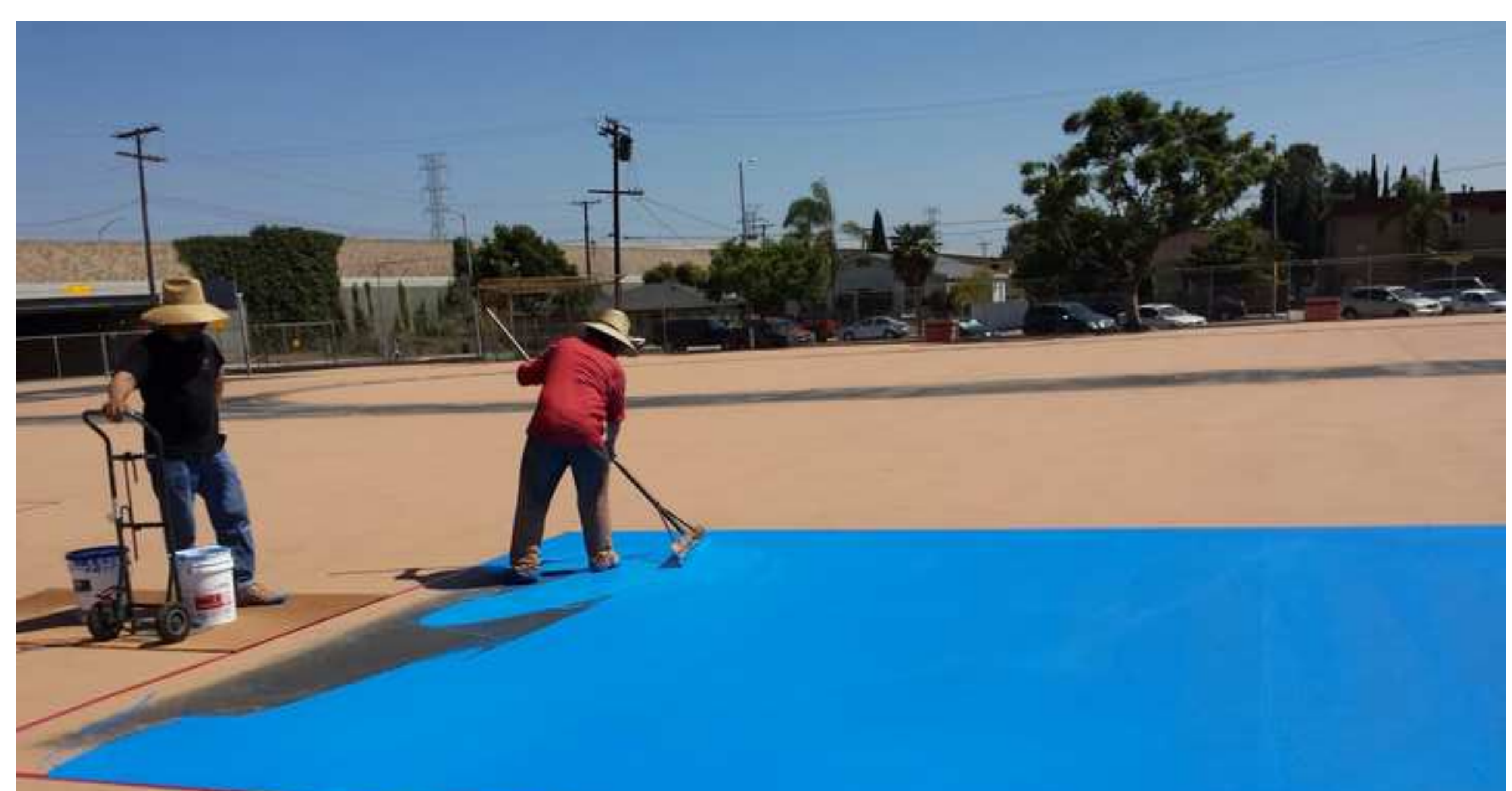

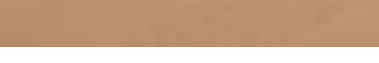

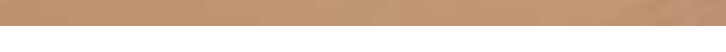

$$
\text { (s) }
$$
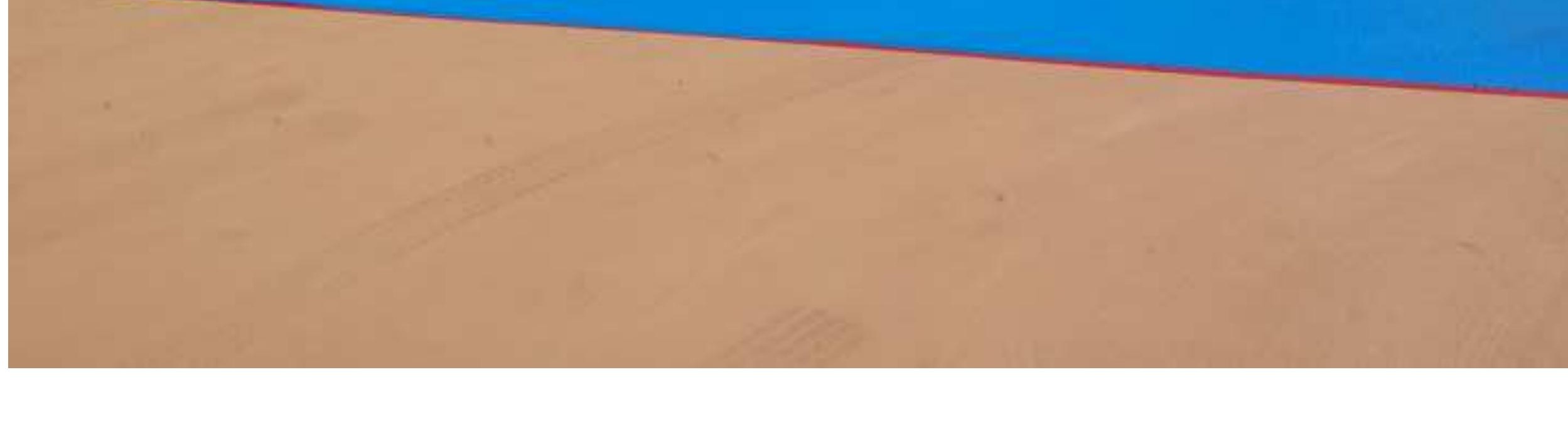
ats

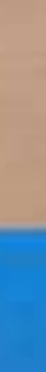






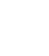

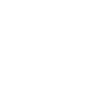

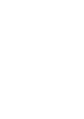
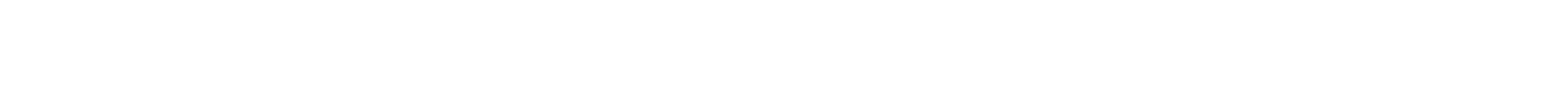


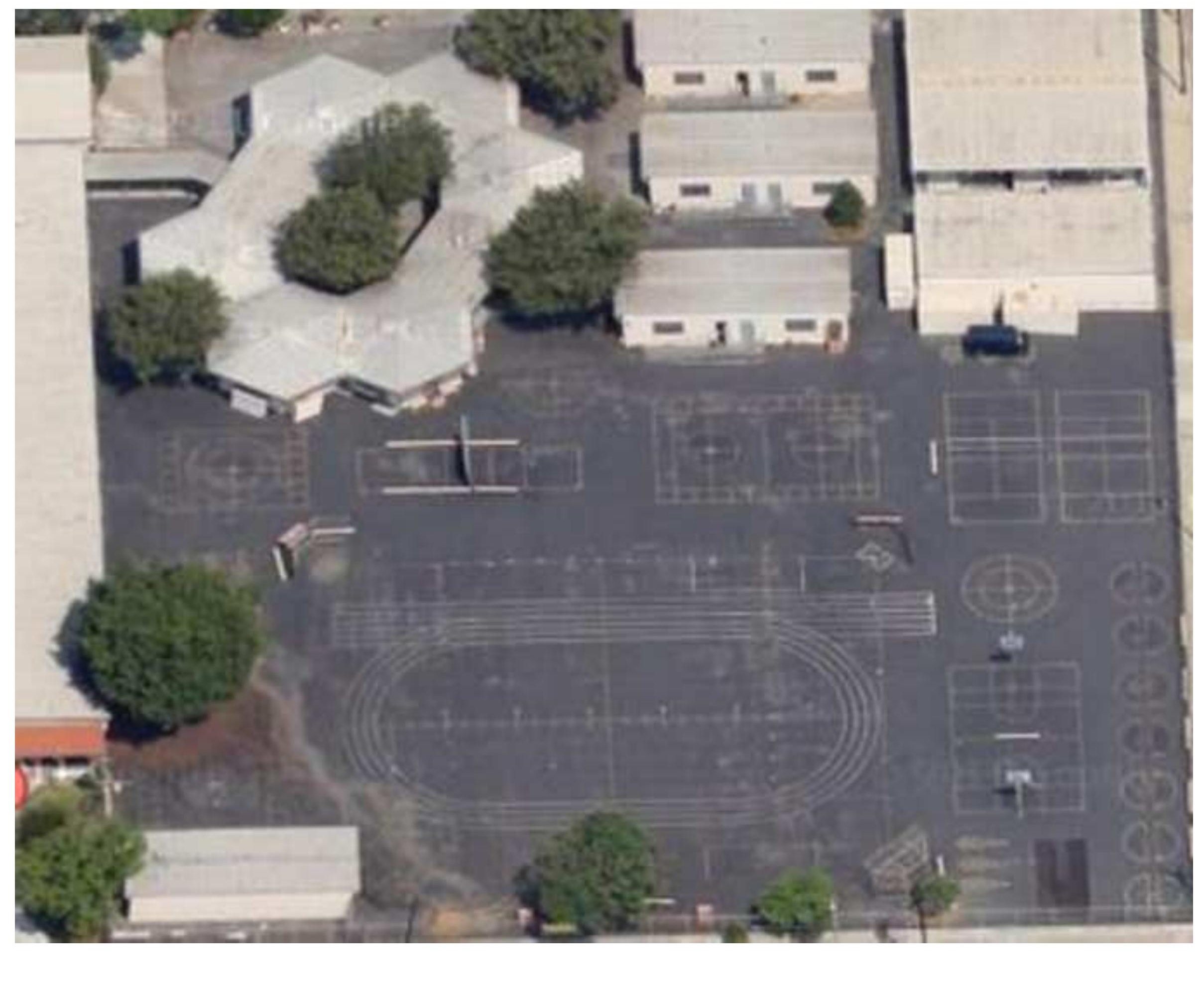

$$
\text { (s) }
$$

\section{s)}

-
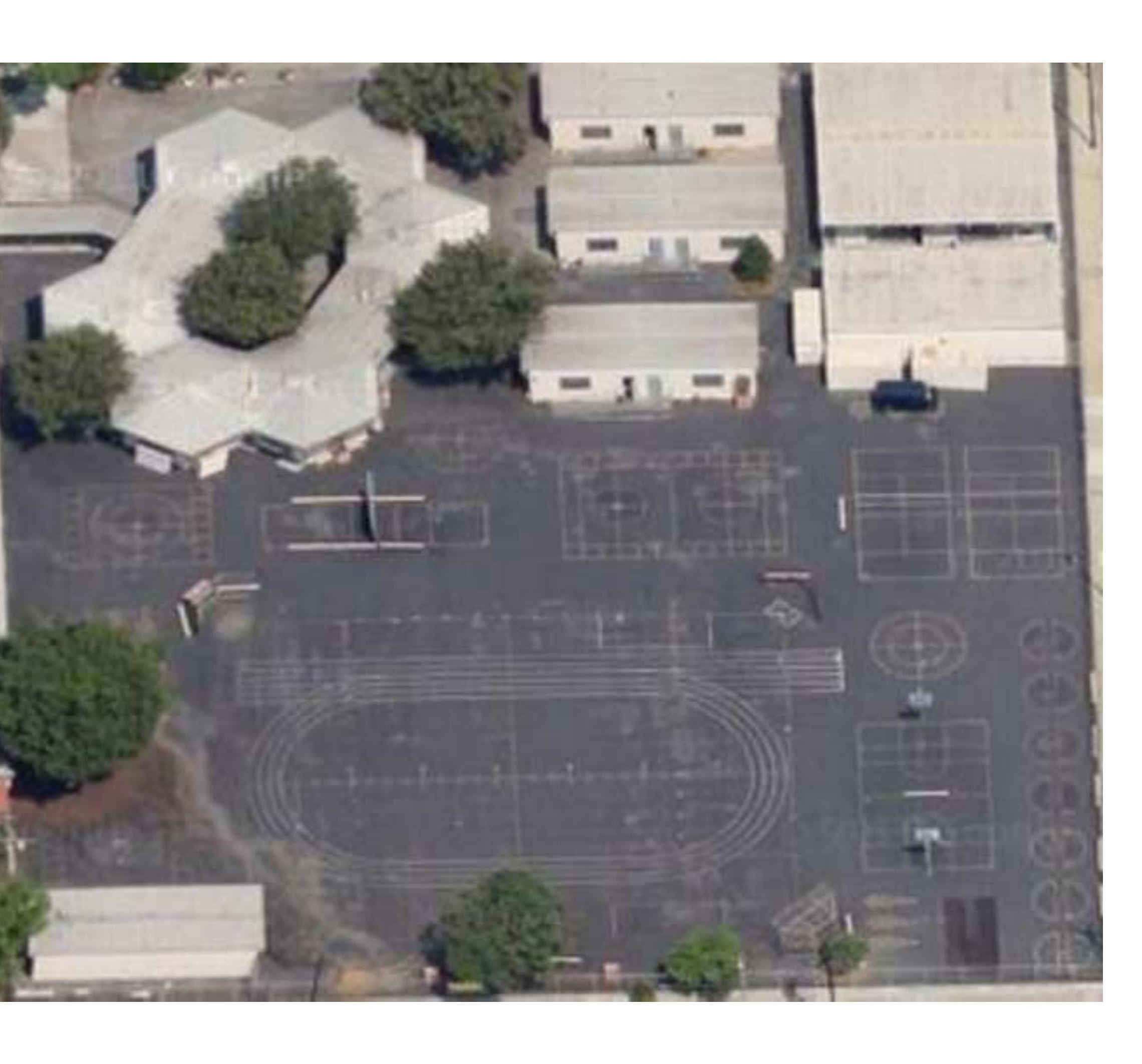

\section{.

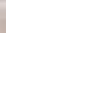
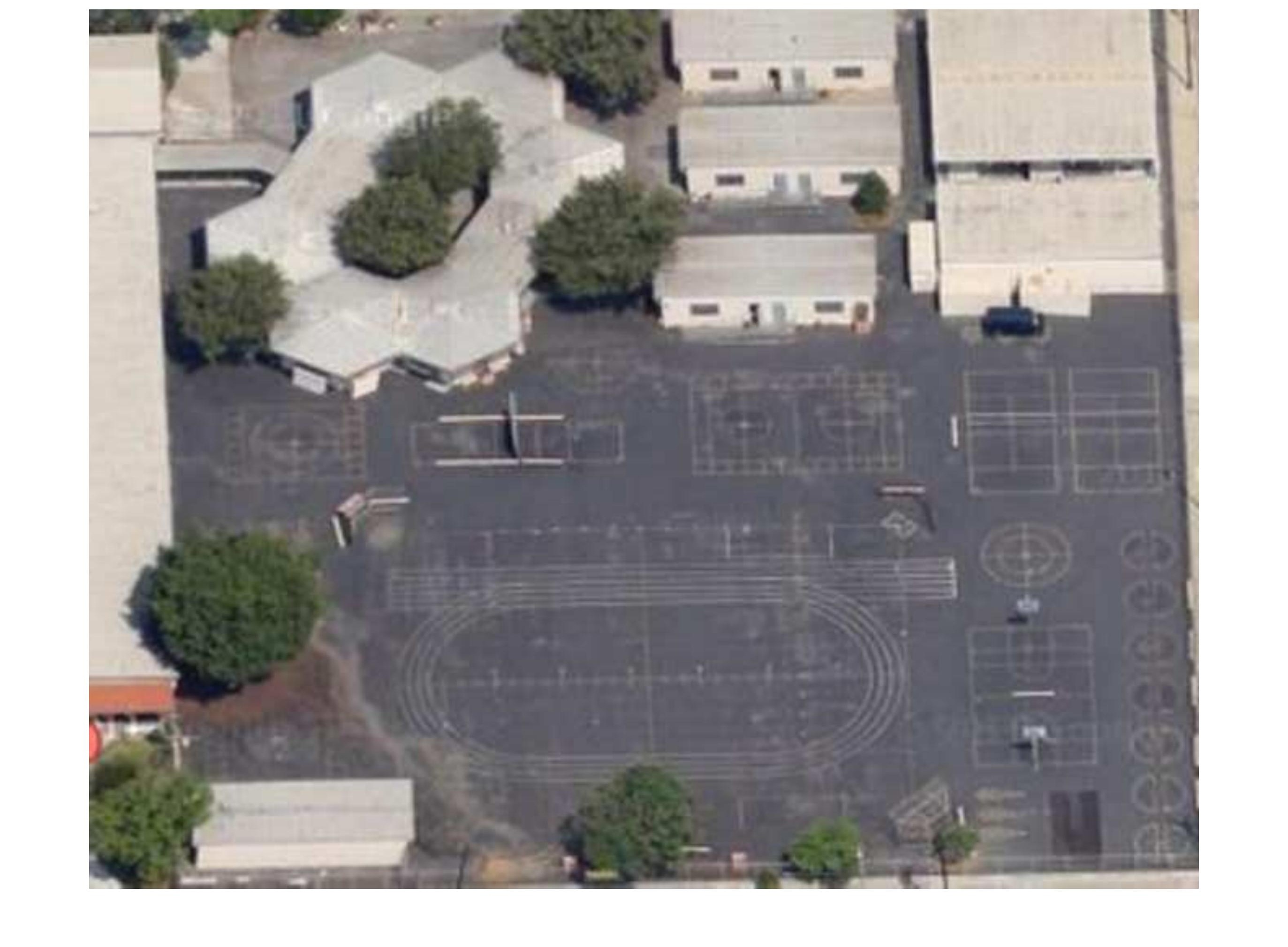


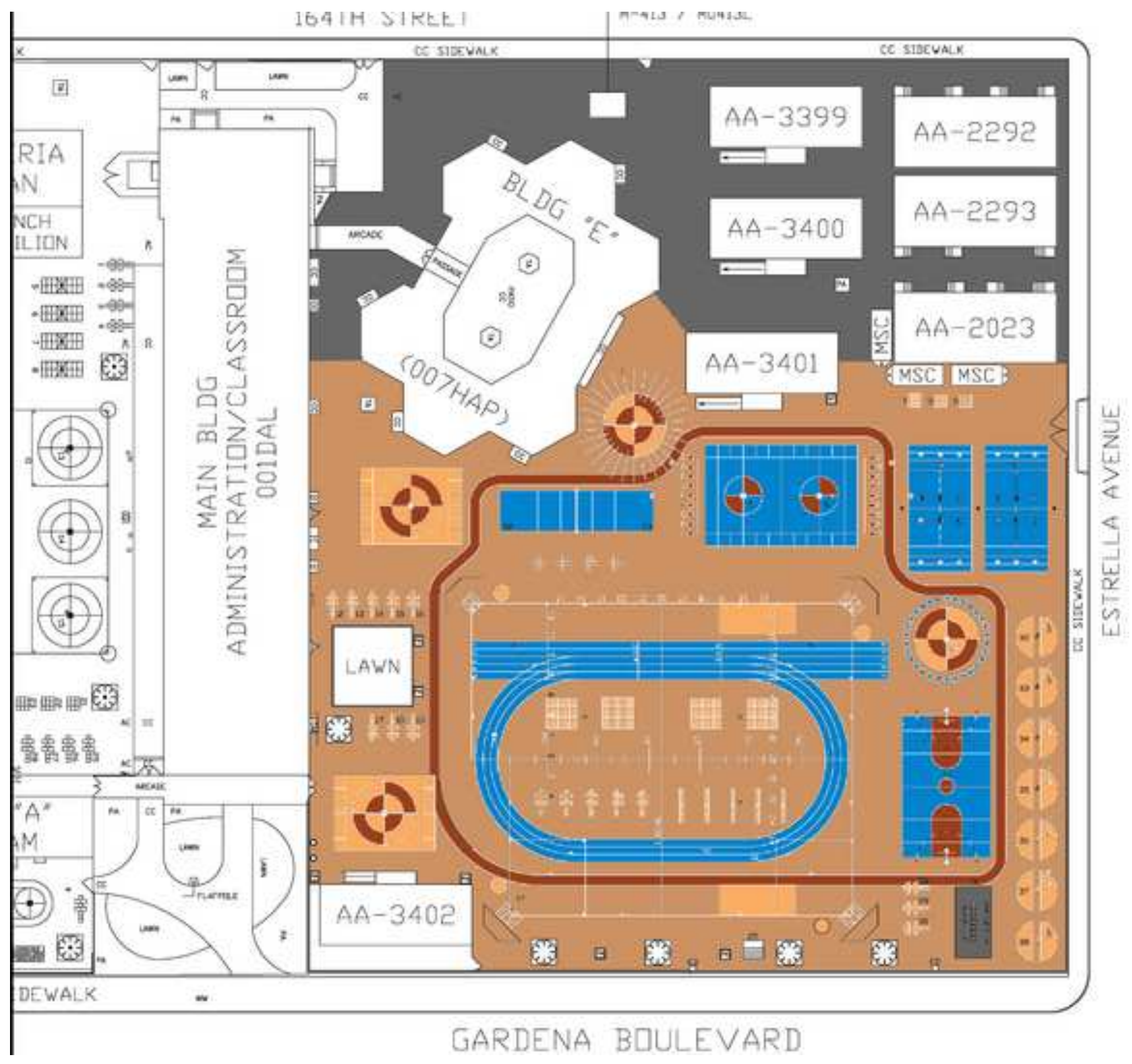




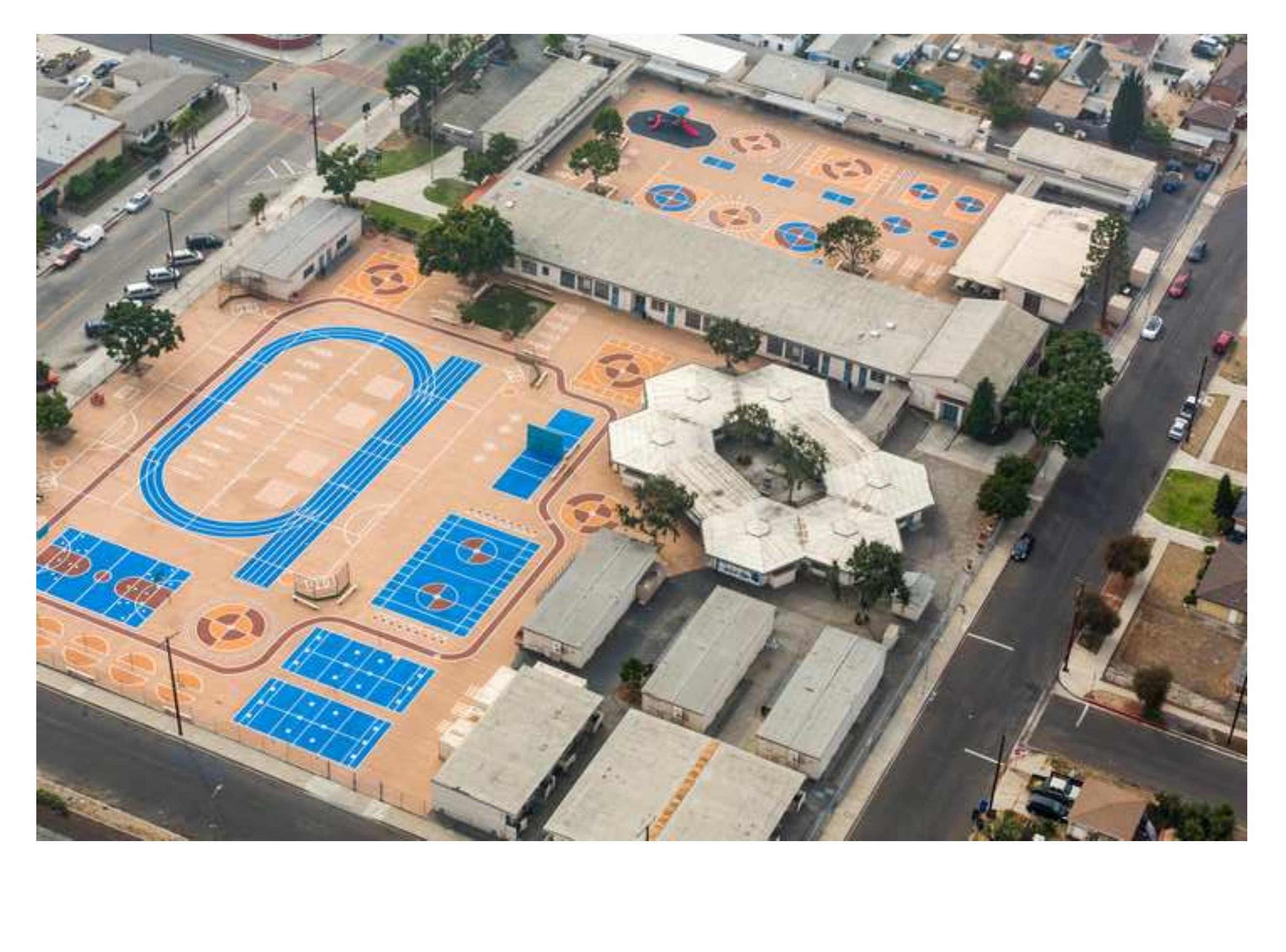

\footnotetext{
.
} 

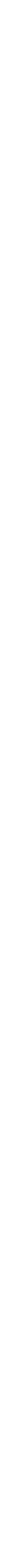